\title{
Reduced Medication in Organic Farming with Emphasis on Organic Dairy Production
}

\author{
By Mette Vaarst ${ }^{1}$ and Torben W. Bennedsgaard ${ }^{2}$
}

${ }^{1}$ Danish Institute of Agricultural Sciences, P.O.Box 50, DK-8830 Tjele, ${ }^{2}$ Royal Veterinary and Agricultural University, Grønnegaardsvej 2, DK-1870 Frederiksberg C.

\begin{abstract}
Medication is an important focus area in organic animal husbandry. The combination of goals relating to improved animal welfare and reduced use of chemicals in general creates a common wish to reduce medication. Based on data from current Danish research projects in organic dairy farming, one specific organic medication pattern or policy cannot be described. The disease treatment pattern is influenced by many factors, e.g. the interaction with colleagues, veterinarians and agricultural advisors. No significant difference could be found with regard to incidence of mastitis treatments or somatic cell counts in 27 organic and 57 conventional herds. A marked tendency to shorter treatment periods in relation to mastitis treatments was described for organic farms in comparison with conventional farms ( 1.9 days versus 3.2 days ( 5 organic and 7 conventional herds)). In a study of development of health advisory service in organic herds, the dialogue between farmer, veterinarian and agricultural cattle advisor changed the treatment pattern markedly during a period of 6 months. Among important future challenges for veterinarians in organic farming is pointed at the constructive, open, and critical interaction with the single organic farmer as well as the organic animal husbandry system in general.
\end{abstract}

Mastitis treatments, medication, organic dairy production

\section{Introduction}

Animal welfare is a key goal of organic farming. A reduced need for disease treatment reflects good animal health and welfare. The rules for organic farming contain restrictions with regard to medication - in order to encourage disease prevention, or even better: health care.

The rules concerning medication in organic farming encourage a more restrictive use of medicine. In Denmark, the withdrawal time after medical treatment on dairy farms is three times prolonged compared to conventional farming, and dispensing of medicine to the farmer for treatment is only allowed for pigs and calves under six month and only if a veterinarian has initiated the treatment. From August
2000, an animal with a life-cycle of more than a year can only be medically treated three times per year - otherwise it is regarded as non-organic and should be converted again. In herds, where there is a substantial need for medical treatments, these regulations will affect the farmers production costs. The rules reflect the overall intention to maintain a good animal health and a wish to ensure consumer protection.

In organic farming, there is a wish to avoid the use of chemicals in general, as a part of the striving towards naturalness. When discussing the possibilities of reducing the use of medicine, focus could be on the 'use of chemi- 
cals alone'. In this case, the goal for organic animal husbandry could be defined as a goal about avoiding treatment independent of the need of treatment. Such a goal can neither be justified from the rules, nor from general animal welfare legislation or considerations. It could also be defined as a wish to replace medical treatments by 'non-chemical treatments'. This is also an expressed wish in organic farming, as stated in the EU-regulation (Anonymous 1999), where it is explicitly mentioned that 'alternative treatment should be preferred, as far as it has proved efficient'. The use of alternative treatment (homoeopathy and phytotherapy mentioned as major alternative treatment methods) must, however, be regarded as second to the wish of an overall improved animal health and welfare. Treatment using so-called alternative medicine is discussed by Löken (2000). The major challenge for organic farming must be defined as a reduction of the level of disease treatment, because it logically follows improved animal health and welfare.

Discussions have been raised in the Danish Veterinary Society whether the legislation for organic farming can cause lack of treatments when needed (Anonymous 1995, 1998). If this is the case, the rules, which should lead to an increased effort for good animal welfare, could lead to the opposite. This aspect of treatment strategies in organic farms should definitely be included in the discussion as a part of discussing veterinary challenges in organic animal husbandry.

The aim of the paper is to discuss veterinary challenges and future perspectives with regard to medication in organic animal husbandry with focus on dairy production. In the paper, results from recent Danish studies (primarily case studies) in organic dairy herds will be shortly presented and form basis for a discussion of the possibilities for reducing the use of medication in organic farming.

\section{Material and methods}

On-farm studies -data collection and short presentation of research projects

Data from three recent on-farm studies has been involved in the following presentation. From all herds in these three studies, central data on milk yield, monthly somatic cell counts, and disease treatments have been recorded. Disease treatments have been checked with veterinarians' recordings by a project veterinarian.

- The 'Kongeå-project' is a project, which is localised in a specific area including three counties in Denmark (around the small river called 'Kongeåen'). This project is led by the Danish Dairy Board and is a kind of an action research project, where a large number of dairy herds form basis for several research projects and seven Ph.D.studies. This project has contributed to this manuscript through data from conventional herds and as a framework for some of the organic herds participating in this study.

- Project 'Mastitis Resistance in Danish Dairy Herds' is one of the projects being a part of the Research Centre for the Management of Animal Production \& Health (CEPROS). One of the aims of this project is through quantitative and qualitative studies to investigate the use of antibiotic treatments in Danish conventional and organic dairy herds, and later to formulate intervention strategies.

- Project 'Development of Health Advisory Service in Organic Dairy Herds' includes 20 dairy herds with agreements with their veterinarian and agricultural cattle advisor about health plans and health service in the herds, and 20 'control herds' (herds with no health advisory service).

\section{Data collection and analysis}

Data has been obtained from central databases as well as on-farm collection by a project veterinarian. Data analyses have been performed 
Table 1. Key figures for production and udder health in 27 organic and 57 conventional herds (participating in the project on development of health advisory service in Danish organic herds and in the Kongeå-project, respectively), during the period December 1998 to December 1999.

\begin{tabular}{lllllll}
\hline & & \multicolumn{2}{c}{ Organic } & & \multicolumn{2}{c}{ Conventional } \\
\cline { 2 - 3 } \cline { 6 - 7 } & $25 \%$ & $75 \%$ & & $25 \%$ & $75 \%$ \\
\hline Number of cows per year & 74 & 130 & & 60 & 93 \\
Milk yield in 1 $1^{\text {st }}$ lactation cows, EKM per day*) & & 19.7 & 23.0 & & 21.7 & 24.6 \\
Milk yield in $\geq 3^{\text {rd }}$ lactation cows, EKM per day & & 22.8 & 28.8 & & 25.8 & 29.5 \\
Mastitis treatments, \% lactating cows per month & & 1.8 & 5.1 & & 3.3 & 6.7 \\
Acute increase in SCSCC, \% lactating cows/month & 5.4 & 7.5 & & 4.8 & 6.7 \\
Chronic elevated SCSCC, \% lactating cows & & 9.4 & 18.6 & & 8.6 & 14.5 \\
Bulk milk SCC (calculated from SCSCC) & 260 & & 401 & & 257 & 330 \\
\hline
\end{tabular}

*) $\mathrm{EKM}=\mathrm{kg}$ milk with $4 \%$ fat content

using SAS Programmes (SAS Inc. 1998) for descriptive statistics (PROC UNIVARIATE, PROC MEANS).

\section{Results}

On-farm studies in Danish organic and conventional herds

In a recent Danish study in 1999 involving 27 organic and 57 conventional herds, the percentage of cows treated for mastitis per month were $1.8-5.1$ ( $25 \%$ and $75 \%$ percentiles) in organic herds and 3.3-6.7 in conventional herds (Table

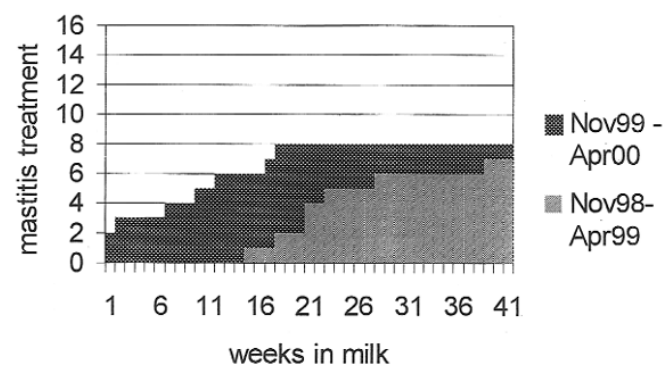

Figure 1. Treatment pattern for first lactation cows during two six months periods, expressed as number of mastitis treatments in relation to lactation stage (weeks in milk). Dramatic changes were made in order to treat the cows earlier in their lactation.
1). The calculated mean bulk milk somatic cell count (SCC) level was higher (single cow recordings) in the organic herds, and more cows had acute or chronic elevated SCC.

In a sample including 7 organic and 5 conventional herds, the duration of antibiotic treatment of acute mastitis was shown to be shorter in average in the organic herds compared to the conventional herds (1.9 treatments per mastitis case vs. 3.2 treatments in conventional herds). Herds were comparable in relation to size and production level.

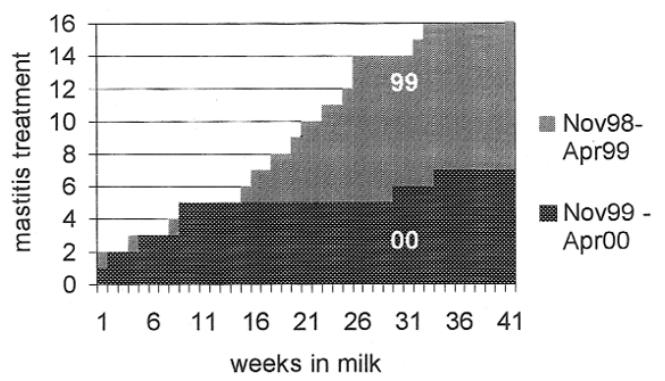

Figure 2. Treatment pattern for cows from second lactation and older during two six months periods, expressed as number of mastitis treatments in relation to lactation stage (weeks in milk). Dramatic changes were made, and cows were in general treated at an earlier stage of lactation. 


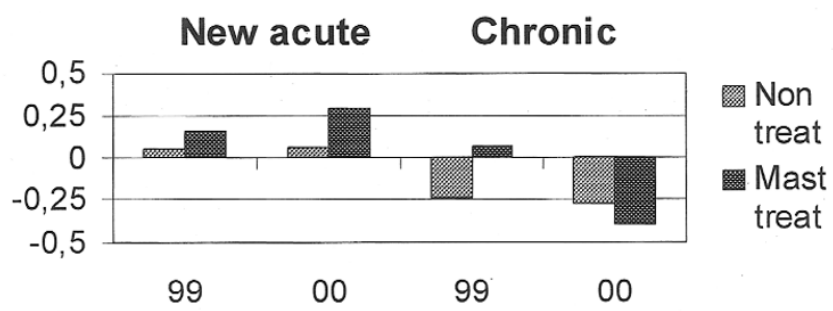

Figure 3. The treatment pattern has changed. The binary response of new acute mastitis ( 0 or 1 for being infected (most likely) or not) allows one to interpret this result as the proportion of acutely infected cows. The continuous score on chronic mastitis has become lower for non-treated cows, indicating that more cows with acutely increased somatic cell counts are treated after one year.

Case study concerning health advisory service The use of medical treatments was followed closely in 20 organic herds with a health advisory service agreement with their veterinarian and their agricultural cattle advisor. The following example is a case study made in one of these herds.

As illustrated in Figures 1 and 2, the treatment pattern changed dramatically within a period of one year. In Figure 1, treatments of $1^{\text {st }}$ lactation cows during two periods of 6 months each are shown. Before the introduction of the health advisory service in the herd, mastitis treatments were exclusively carried out from 15 weeks after calving onwards. After introduction of the health advisory service, heifers were treated immediately at first sign of an infection. No heifers were treated later than 18 weeks post partum, for mastitis. A similar pattern is described for older cows (Figure 2), where cows now are treated during the first $2 \frac{1}{2}$ months after calving except a few cows treated in connection to drying off.

In Figure 3 it is illustrated that far more cows with acute signs of mastitis (increased somatic cell counts) are now treated. At the same time, the chronic mastitis score (a continuous score based on the latest three somatic cell counts) has become significantly lower for mastitis treated cows.
In this herd, the farmer couple, their veterinarian and their agricultural cattle advisor have agreed on a long term strategy for the herd. This strategy includes improvement of the conditions for heifers, improvement of the housing conditions, and introducing of milk samples for bacteriology in older cows before drying off, if they have shown signs of mastitis during the lactation.

\section{Discussion}

Preliminary results from on-going studies have been presented in order to illustrate different aspects of the use of medication in organic herds of today in Denmark. It seems obvious that organic farming is an area in dynamic development, where a 'characteristic unambiguous organic pattern of medication' cannot be found. The choice of treatment on single animal level as well as on herd level depends on goals of the single farmer, interaction between farmer and co-workers (veterinarian, agricultural cattle advisor and others), and local attitudes. It is relevant to discuss in more details which factors may influence the use of medication in the context of each organic herd as well as in the context of organic farming in general. It also seems relevant to define which goals and possible guidelines organic dairy herds may have for disease treatments in their herds. 
On-farm studies in Danish organic and conventional herds

Udder health data from organic herds in 1999 showed a tendency to a less good udder health, compared to conventional herds. In a previous Danish study, the opposite was shown (Vaarst \& Enevoldsen 1994). There was a significantly lower incidence of mastitis treatments in organic herds compared to conventional herds, and this was furthermore reflected in lower somatic cell counts, based on bulk milk samples as well as monthly milk samples on cow level. The results in this previous study were explained by a very consequent and immediate reaction to mastitis signs, a great effort from the farmers (extra milking out by hand etc.), and much care taking. Strategies including culling, drying off single udder glands and letting cows with high somatic cell counts stay together with a number of calves may also be factors improving the somatic cell count on herd basis. There was no evidence that the 'organic farming itself' (the feeding, use of straw bedding etc.) improved udder health, since a wide spectrum of udder health results were found in these herds. The management by the farmer seemed to be far the most important factor.

The shorter duration of antibiotic mastitis treatment in organic herds may be explained by restrictions on use of antibiotics because the organic farmer are not allowed to make follow up treatments with antibiotics in the organic herd. This affects the price of treatment relatively much. The low number of farms should be noted, although the difference is marked. The risk for antibiotic resistance should be discussed in connection to this treatment pattern (one or very few treatments per disease case). In the following years, the level of antibiotic resistance will be continuously measured, also in organic herds.
Case study concerning health advisory service It was demonstrated that an active, explicit and goaloriented treatment strategy could lead to changes of treatment patterns. In this case, a strategy was developed and followed up through dialogue between farmer, veterinarian and the agricultural cattle advisor. In an investigation based on group focus interviews among newly converted Danish organic farmers (Vaarst 2000b, Vaarst et al. 1999), the attitude of the veterinarians towards organic farming was in many cases described as very critical. The veterinarians were described as not being aware of the specific needs of organic farmers (e.g. advice on how to keep milk fed calves outdoors - an area, which was described as unfamiliar to most veterinarians).

The role of the veterinarian in converting and converted organic herds

In a parallel interview investigation among Danish veterinarians about their experience in and attitude to organic farming (Vaarst, 2000a), some veterinarians expressed frustration of not being a part of the conversion process. Both farmers and veterinarians expressed that focus on the herd (the animals) during the conversion was minor, and no specific 'organic steps' were taken. Loose housing systems were often introduced in relation to conversion, and the feed ration was changed. Nevertheless, the stop for use of pesticides and chemical fertilizers in the field was described as the major challenge for the organic farmer, and the herd could be managed more or less 'as the same', also after conversion. It may be expected that the attitude to animal health and treatment with chemicals would lead to treatment patterns that can be characterised as 'specifically organic', but so far, this is not the case. Both the present udder health results and the expressed frustration, confusion and statements about the relatively vague role of the veterinarians in the organic 
herds may stress the need to include the veterinarians more in the whole building up, strategy planning and daily life of the organic herds. A prerequisite for this is the presence of a herd related veterinarian, who understands the basic goals and intentions of the farmer - both in relation to the herd situation and in relation to being a part of the organic farming system. This may take time, and include a process of 'conversion' for all involved persons (Vaarst 2000b) - but it definitely points at a number of challenges and possibilities for a fruitful dialogue, which has not been present within the framework of organic animal husbandry until now.

In this study, several patterns of interaction between veterinarian and farmer are described. Current qualitative studies of treatment patterns has shown that treatment decisions are very complex and involves different levels of decision making, including mastitis symptoms, cow characteristics and herd priorities in various degrees (Vaarst \& Paarup-Laursen 2000). These studies also show that both the person specific priorities of the farmer and the veterinarian, and the dialogue between these people involved in treatment decisions are factors of decisive importance for the choice of treatment strategy.

\section{General discussion about responsible veteri-} nary medical treatments

What is responsible action towards a diseased animal? Is antibiotic treatment of an old cow with repeated cases of mastitis involving $S$. Aureus more responsible than milking out, udder massage, peppermint oil and more bedding material? Do the organic rules influence treatment pattern more than the general low milk and meat prices, when giving priority to disease treatments? Who looses money - in the end when avoiding treatment of animals needing treatment? These - and more critical, new and relevant questions can be asked, and the answer is one of the current veterinary challenges!

\section{Conclusion and future veterinary challenges}

Focus on animal welfare and health promotion is a fundamental goal in organic animal husbandry. This should be the primary goal of each herd, and improvements in animal health and welfare should initiate and direct reductions in medication. The challenge for veterinarians is to work with the goals of organic farming - as veterinary professionals - and go into a dialogue with farmers and other co-workers of the farm. The goals are not the rules - veterinarians should be dialogue partners of the farmers by giving both goals and rules meaningfulness and 'life' through a concrete content and actions in accordance with the basic aims of organic farming.

If focusing on the 'chemicals-question', alternative treatment methods - e.g. homoeopathy may be relevant. These methods can only be generally recommended, if there is good experience with regard to a positive effect of treatment, or if scientific results show an effect of the remedies, and only if there is professional knowledge about the alternative treatment involved.

In general, the need for a more critical, more explicit and more active choice of treatment strategies seems relevant, and should be developed in a co-work involving farmers, veterinarians and agricultural cattle advisors.

\section{Acknowledgement}

Thanks to the farmers - organic as well as conventional - for access to data and knowledge on treatment procedures on the farm. The farmers Gerhard \& Jytte Horst, their veterinarian Peter Andersen and their agricultural cattle advisor Peter Ringgaard Jessen are particularly acknowledged for sharing their thoughts and ideas with regard to mastitis treatment patterns in the herd with us. Project colleagues are acknowledged for their constructive contribution to the discussions, data collection and problem solving of all kinds in the herds. 


\section{References}

Anonymous: Det dyreetiske Råd, Udtalelse om økologisk husdyrproduktion. [Animal Ethical Council in Denmark: Statements on organic animal husbandry]. [In Danish]. 1995.14 pp.

Anonymous: Editorial. Dansk Veterinærtidsskrift, 1998, 81 (9), 337.

Anonymous: EU Regulation. 1804/1999, 19th July 1999. European Union Bulletin, 1999, 222:1-28.

Löken T: Alternative treatment in organic farming, 2000, ibid.

SAS Institute Inc: The SAS system for Windows release 6.12, 1998.

Vaarst M: Omlægning til økologisk drift set fra dyrlægers og konsulenters synsvinkel [Conversion to organic farming seen from the view point of veterinarians and agricultural advisors]. In: Kristensen ES \& Thamsborg SM (eds.): Animal health, welfare and medication when converting to organic dairy production. Report, Danish Centre for Organic Farming [In Danish], 2000a, 1546.

Vaarst M: Landmændenes oplevelse af omlægning til økologisk drift [The farmers' experience of conversion or organic farming]. In: Kristensen ES \& Thamsborg, SM (eds.): Animal health, welfare and medication when converting to organic dairy production. Report, Danish Centre for Organic Farming [In Danish], 2000b, 47-63.

Vaarst $M$, Enevoldsen $C$ : Disease control and health in Danish organic dairy herds. In: Huisman EA, Osse JWM, van der Heide D, Tamminga $S$, Tolkamp BJ, Schouten WGP, Hollingworth CE, van Winkel GL (eds.): Biological basis of sustainable animal production. Proceedings of the Fourth Zodiac Symposium, Wageningen, The Netherlands, April 13-15, 1993. EAAP Publication No. 67, 1994, 211-217.

Vaarst M, Paarup-Laursen B: Landmandens håndtering af mastitis vurderet ved kvalitative interviews. [Mastitis control carried out by the farmer, evaluated through qualitative research inter- views. In Danish]. 2000. In: Houe H (ed.): Sundhedsstyring i kvægbesætninger med focus på mælkefeber og yversundhed. CEPROS Report No. 6, 2000, 79-88.

Vaarst M, Thamsborg SM \& Kristensen ES: Animal health and welfare aspects in organic dairy production systems. In: Hermansen JE, Lund $V$, Thuen E (eds.): Ecological Animal Husbandry in the Nordic Countries. Proceedings from NJFseminar No. 303, Horsens, Denmark, 16.-17. Sep. 1999, 1999, 161-164.

\section{Opsummering}

Medicinanvendelse er et vigtigt fokusområde for økologisk husdyrhold. Kombinationen af mål vedrørende høj dyrevelfærd og reduceret anvendelse af kemiske stoffer skaber et fælles mål om at reducere medicinforbruget. Et specifikt 'økologisk behandlingsmønster' kan ikke beskrives ud fra foreløbige resultater af danske igangværende studier i økologisk malkekvægbrug. Behandlingsmønstret i den enkelte besætning påvirkes blandt andet af omlægningstidspunktet og samspil med kolleger, dyrlæger og konsulenter. Der blev ikke fundet nogen signifikant forskel mellem to grupper på henholdsvis 27 økologiske og 57 konventionelle besætninger med hensyn til mastitisbehandlinger og celletal. I et case-studium blev der fundet en markant tendens til en kortere behandlingsperiode i (5) økologiske besætninger sammenlignet med (7) konventionelle besætninger (1,9 dage i økologiske og 3,2 dage i konventionelle besætninger). I et projekt om udvikling af sundhedsrådgivning i økologiske besætninger kunne det vises, at dialog mellem landmand og rådgivere kunne ændre behandlingsmønstret indenfor en periode på seks måneder. Blandt vigtige fremtidige udfordringer for dyrlæger, som arbejder i økologiske besætninger, peges der derfor på vigtigheden af et konstruktivt, åbent og kritisk samspil med den enkelte økolog såvel som med den økologiske driftsform generelt. 